\title{
SUCCESSION POLITICS AND STATE ADMINISTRATION IN AFRICA \\ The Case of Zimbabwe
}

\author{
Arthur Fidelis Chikerema and Ogochukwu Nzewi \\ Arthur Fidelis Chikerema is a lecturer in the Department of Politics and Public \\ Management, Midlands State University, Zimbabwe \\ Ogochukwu Nzewi is a professor in the Department of Public Administration, \\ University of Fort Hare, South Africa
}

\begin{abstract}
The paper is a critical inquiry into the influence of succession politics on state administration in Africa, with particular reference to Zimbabwe, and unpacks the interactive boundaries and conceptual overlaps in this field. This study was based on 18 qualitative in-depth interviews conducted with key informants using the purposive sampling technique, complemented by extensive document review. The findings of the study show that succession politics in Africa includes executive dominance, egocentrism and excessive appointive powers. These are compounded by the lack of an institutional framework of succession, which in turn undermines the professional independence of the bureaucracy and inhibits the pursuit of comprehensive governance. The findings also isolate Zimbabwe as a victim of political, societal and historical factors that exacerbate the succession dilemma. In its recommendations, the paper argues that the succession challenge faced by the continent, in particular Zimbabwe, will continue to hound succession trends and responsive administration unless broad-based reforms are instituted to dismantle the historical legacies embedded in the political systems.
\end{abstract}

Keywords: succession politics, state administration, constitutionalism, regime change, Zimbabwe

\section{INTRODUCTION}

Succession politics is understood to mean the process of changing leadership and includes the vacating of power by the old ruler, the choice of the new, and his or her legitimation. Periods of succession are often tense for all regimes, even 
where there are established procedures and easy legitimation. Succession times are considerably more risky and precarious for tyrannical, authoritarian and dictatorial regimes. The discourse of succession presents a contested and topical issue in Africa, and in particular Zimbabwe. Afrobarometer surveys (2015) on political succession have shown that leaders in African countries manipulate and exploit state apparatus to further their interests at the expense of promoting an efficient, effective and responsive government characterised by peace, stability, democracy and the growth of the political economy. This view is compounded by muzzling dissent, cumulating in strong personalities and weak institutions. The argument of strong personalities and weak political institutions has wide application in Africa, since some leaders view political leadership as a solo project rather than a collective political process. Therefore, passing the baton to the next leader has been a challenge resulting in the personalisation of governments and political parties by leaders.

Political and administrative organs are crucial components for the effective functioning and development of nations since there is a direct correlation between the configuration of the political architecture and the functionality of the administrative apparatus of the state. The political dynamics of a state influence changes in the administrative leadership, since the political architecture determines the turnover of administrative staff. Regular transfer of executive power is the major test of stability in a nation's political system. In many African countries leaders have shown a consistent trajectory of amending state constitutions to prolong their stay in power.

Nonetheless, the succession outlook is not completely gloomy in Africa, as several countries offer good examples of peaceful and orderly leadership change. These include, most importantly, Nigeria, as well as South Africa, Botswana, Mauritius, Senegal, Mozambique, and Ghana (Habisso 2011). Despite the few good examples of routine regime change, it is apparent that incumbent leaders in many African countries have seized power from both political parties and governments. The result is a stifling of leadership renewal and reconfiguration of governance structures resulting in the collapse of administrative units and statutory state organs. Zimbabwe had only one leader from independence in 1980 until the military-aided transition on 17 November 2017. This paper strongly argues that a proper succession plan, pertinent constitutionalism and ingrained succession norms are the mainstay and lifeblood of succession challenges in Africa.

\section{HISTORY OF SUCCESSION POLITICS}

Historically, the term succession was applied to monarchies, signifying the substitution and replacement of one sovereign by another (Hughes \& May, 1998). Hughes and May (1988) further aver that in hereditary monarchies there tend to 
be less frequent clashes over the authentic or legitimate heir or beneficiary. In most monarchical regimes, traditional authority was recognised as legitimate by virtue of tradition, custom, and the veneration of previous generations. Under this form of political system, laws and customs are handed down from earlier generations to validate the existing political structure (Nwosu 2012, p. 10), and the transmission of authority is normally heritable in monarchies. Thus, there are few if any succession problems since there is a solitary succession framework that is usually followed after the death of the monarch.

The progressive bureaucratic state has embraced a legally-sanctioned rational succession procedure in which authority is derived from a system of rules that are agreed to by the population (Hughes \& May 1988). In this rational procedure, states become progressively bureaucratic, monarchs either become figureheads or disappear, and government shifts to political parties and party coalitions (Govea \& Holm 1998, p.135). Most modern states have shifted from the traditional/ monarchical succession framework to that of legal-rational succession (ibid.). The succession problem in Africa, however, seems to be characterised by the postcolonial state coupled with political power as a means to accumulate riches (Igbuzor 2010, p. 6). This results in the gradual attrition of the constitutive and regulative rules, institutional processes and mechanism for succession leading to political volatility, illegitimate governments and conflict.

In Zimbabwe, the Constitution provides for an elective congress to elect party leadership and/or renew their mandates. However, the paper points to the capture of procedure through strong normative values, thus undermining the role of the elective congress as a democratic institution because leaders had used it to endorse themselves. The paper examines the constitutional framework and succession paradigms in Zimbabwe juxtaposed with the tenets of democracy and good governance. These include the entrenchment of constitutionalism and the institutionalisation of systems for regular political succession as key ingredients for stability and growth.

\section{THE CONCEPT OF SUCCESSION POLITICS}

Succession politics has been defined as the transfer of political power from one person or group, government or regime to another (Ojo 2009, p. 9). Hughes and May (1988, p.11) agree that succession politics is 'the manner by which political power passes, or is traded, from one government or administration, to another'. They further describe succession politics in its narrow sense as the methodical arrangement for the transfer of important offices within a state, which offers latitude for change and coherence, and further aver that the degree to which power is successfully traded becomes a benchmark of the political development 
and maturity of a state. Examples include mature democracies like Britain, France, and Germany as well as African countries such as Mauritius, Botswana and South Africa that have experienced seamless succession. Succession takes different forms; for Mwaura (1997, p. 7), leaders can be succeeded through regular executive transfer, irregular power transfer, internal procedures within the ruling party, renewal of executive tenure, or self-succession and executive adjustments. Power transition in Zimbabwe was witnessed only twice, immediately after independence in 1980 and again in the military-aided transition of 17 November 2017. It is evident from these examples that most transitions in Africa have been irregular, signalling the need, addressed in this paper, to recommend a constitutionally-based rotation as in mature democracies.

The paper argues that African polities should confront a more general problem, namely how to organise their governments. Zimbabwe seems to be one of the prime examples of power revolving around the person of the president. The complete domination of Zanu-PF by the presidency, and the primacy of one centre of power, have sustained patrimonialism in Zimbabwe (Bratton \& van de Walle 2010, p. 25). This in turn has resulted in the collapse of the administrative units of the state due to excessive political interference and control. Political systems and processes in many African countries revolve around the presidency. Devanny and Jowell $(2018$, p. 3) advanced the notion that succession politics is one of the most delicate issues in politics, claiming that political leaders seem reluctant to handle succession issues, firstly by arbitrarily extending office term limits, and secondly by revising a country's constitution to permit another presidential term.

From this perspective Zanu-PF appears to thrive on neo-patrimonialism, the cult of personality and politics of patronage (Francisco 2010, p.14). The incumbent party seems to have used state resources to reward its supporters at the expense of implementing government programmes, in many cases appointing party loyalists to strategic positions in state institutions. For example, at least $15 \%$ of the Zimbabwe Electoral Commission (ZEC) employees are serving and former security personnel, and it can be reasonably assumed that they are there to advance the interests of Zanu-PF. The paper thus asserts that succession politics in Africa resembles and reflects a negation of the legal rotational succession framework designed to guarantee a seamless power transition in Africa.

\section{STATE ADMINISTRATION}

State administration in a polity is determined by the politics of the day. How public decisions and policies are made is influenced by those who control the levers of power. The paper argues that state administration is the engine and life blood of government programmes whose role is to fulfil and attain the 
aspirations of both governors and the governed. Agamben (1989, p. 40) contends that approaches to public administration constitute related activities; for instance, public administration deals with the administration or management of issues which have to do with society, politics and its sub-parts which are fundamentally not private, commercial or individualistic. Maphunye (2009, p.15) characterises state administration as a politico-regulatory structure with the ability to convey administration to people in general. This exceeds the criteria for a trained and insightful bureaucracy that simply enacts arrangements from a bureaucratic perspective. Rather, it is the subordination of administrative structures and the overlooking of constitutional mandate by the political structure that have negated the design of strong democratic administrative structures in Africa.

\section{THE COLLUSIVE MODEL OF POLITICO-BUREAUCRATIC STATE ADMINISTRATION}

There are a number of politico-bureaucratic relations that inform the discourse of state administration the world over, namely the collaborative, collusive, intrusive and integrated models. Of concern to the present paper is the collusive model that depicts the state of affairs in Zimbabwe where democratic centralism has defined the political landscape, suffocating the elasticity and autonomy of state institution and statutory organs.

This model is characterised by a close relationship between political and bureaucratic elites based on low role separation, a model that accords with predatory patrimonial states with low, sometimes non-existent bureaucratic independence. This collusive relationship nurtures patronage networks to extract party allegiance and is more obvious in predacious states such as Zimbabwe (Dashwood 2000, p. 30). It is also associated with relatively democratic countries such as Mexico, where politics is dominated by a patronage system (Grindle 2012, p. 45). The relations are characterised firstly, by control of the state apparatus by a small assemblage of politicians and bureaucrats with personal links. Secondly, those in strategic political and administrative positions have access to the main means of securing personal affluence in the country; thirdly, the government bureaucracy is used largely for rent-seeking resolves; and finally, employment in the public service is based on allegiance to politicians, leading to enormous and inept bureaucracies.

The paper stresses that patrimonial states in Africa resemble overgrown bureaucracies incorporated into rent-seeking governments. This pervasive corruption is widely seen as a central cause of the post-independence economic stagnation across the continent (Grindle 2012, p. 18). The problem, however, has to do with the lack of bureaucratic autonomy. A key feature of the collusive model is 
that engagement in the bureaucracy is centred on personal or political allegiance. The patronage system in the collusive model entails the employment contract to be centred on a personal or political allegiance to an individual. In systems with an established civil service, this contract tends to be between an individual and an institution. It is also worth noting that because there are often political cliques and conflicts within patronage systems, such systems are 'often quite muddled' (Grindle 2012, p. 20). The model tends to promote a strong patrimonial and patronage system, which normally results in a static environment in which leaders are not rotated because of a captured bureaucracy.

The paper asserts that the politico-administrative interface tends to promote symbiotic relations between these two agents to achieve the common good. A politico-administrative interface is vital for effective public sector governance, where the administrative organs are comparatively apolitical and have minimal political patronage (Cedras 2013, p. 75). Once voted into power, political parties have a bearing on the governance of the polity. Appointments of senior government officials depend on the government of the day, and those appointed often reflect the political trajectory of those in power (Mills 2012, p. 28). Succession politics should take a governance approach premised on responsiveness, responsibility, economic development and political security (Oyedele 2015, p. 34). The adoption of a collusive model in Africa with reference to Zimbabwe undermines and neglects the development of a strong and responsive public administration (Cedras 2013, p. 60). Moreover, there is confusion between policy pronouncements which are the preserve of politicians, and policy implementation which is considered to be the purview of public administrators. Professional public administration seems to have become subordinate to politics in Zimbabwe (Matunhu 2011, p. 27). This has resulted in the collapse of units in the administration and statutory state organs. In this context, state administration should have high standards of professionalism and efficiency, be economical, development-oriented, impartial, fair and equitable, and without bias. Furthermore, state administration, as the bastion of responsible government, should be accountable, cooperative and transparent. Often, political agents in control take for granted and underestimate the role of administrative units, forgetting that what needs to be done will be implemented by the administration. Therefore, the transition from a parliamentary to a presidential system in Zimbabwe led to the usurpation of both the political and administrative roles of government by the political leadership, as espoused by sections 89 and 90 of the Zimbabwean Constitution. To this end, therefore, the paper advocates a symbiotic and collaborative politico-administrative interface that promotes seamless leadership succession and effective state administration in Zimbabwe. 


\section{METHODOLOGY}

This paper explores the impact of succession politics on state administration in Zimbabwe, and has four research aims:

- to examine the similarity between constitutional discourses and normative narratives in succession politics;

- to examine the influence of party politics on the functioning of public administration systems in Africa with particular reference to Zimbabwe;

- to examine challenges posed by succession politics on state administration; and

- to recommend a succession mechanism or paradigm for effective state administration in Zimbabwe.

The research was based on non-probability sampling procedures, and participants were selected because of convenience and their knowledge of the subject under study. For instance, politicians, think tanks, civil society and academia had an enhanced chance of being part of the sample in the thematic area of succession and state administration.

Table 1: Interview response

\begin{tabular}{|l|c|c|}
\hline Population group & Targeted & Actual \\
\hline Executive Branch & 2 & 2 \\
\hline Legislature & 3 & 3 \\
\hline Bureaucracy & 4 & 3 \\
\hline Politburo members & 4 & 2 \\
\hline Opposition parties & 40 & 3 \\
\hline Think tanks & 3 & 2 \\
\hline Academia & 60 & 3 \\
\hline TOTAL & & 18 \\
\hline
\end{tabular}

Source: Raw Data

The researcher interviewed representatives of three political parties, representing a 7.5\% proportion of the total number of 40 opposition political parties as indicated in Table 1 above. The political parties represented in the respondent sample are only those that are represented in the House of Assembly. Whereas the researcher appreciates that political parties have various formal and informal avenues of 
influencing state administration, Parliament remains the most viable framework for members to hold the executive accountable. Section 117 of the Constitution provides that Parliament shall be responsible for ensuring that governmental institutions and organs at both national and sub-national level are bound by the Constitution. In the categories, the response rate was over 75\% and in all those cases data collection saturation was reached. Any interview above the saturation point would therefore not be of research information value but rather constitute a data collection exercise only without offering a corresponding qualitative value.

\section{PATRONAGE POLITICS, STATE ADMINISTRATION AND PATRIMONIALISM}

This section focuses on how patronage politics and patrimonialism influences succession patterns, frameworks and the efficacy of state administration. Members of academia, think tanks, civil society and two of the MPs strongly agree that patrimonial systems in most African nations seem to have adversely affected the challenge of non-succession. One representative of the opposition party noted that:

The calibre of most African nationalists was engrossed in power accumulation and consolidation at the expense of development and redesigning of governance structures/institutions. Ascendance to power meant perpetuation of neo-patrimonial system and patronage politics.

Such reasoning suggests that leaders seem to be concerned with consolidating power through expanding their electorate and patronage networks at the expense of stability and continuity of a polity. The views above of the member of the opposition were echoed by Dorman (2006, p. 6), who asserts that African politics 'is increasingly patrimonial and benefits oriented'. In patrimonial contexts, control is cohesive or compacted in one individual who applies it for his subjective gain, and faithful supporters are rewarded. Dorman (ibid.) further notes that 'These cohorts or proxies are obligatory to mobilise political help for the incumbent and alluded to conclusions made by the patron'. A case in point is the manipulation of land reform by Zanu-PF to entice war veterans to become the vanguard of the party; they in turn campaigned for Zanu-PF as a sign of loyalty.

In the same context, the academics strongly agree with the opposition member and believe that political business in Africa is influenced by cartels controlling those with the levers of power. Furthermore, the cartels are well linked and protected and this is made easier by their ability to seize major state institutions, including those charged with oversight - the police and anticorruption courts. A lecturer at the Midlands State University commented that: 
Political systems in Africa are characterised by well-webbed cartels enjoying the protection of the political elites. The cartels thrive within an intently knit system of close connections. The cartels are awarded tenders in major sectors of the economy namely agriculture, fuel sector, mining and energy. The network is difficult to prosecute since the connections enjoy the protection of the powerful. On the other hand, the cartels support the political elites' political programmes, for instance funding constituency development programs and other personal goodies. This fuels succession challenges, since cartels will protect the systems that benefit them.

The academics interviewed noted the capture of Command Agriculture and the fuel sector by the Tag wirei family in Zimbabwe who have close connections with the political elite, especially in the presidency. On January 182020 Nehanda Radio reported that fuel mogul Tagwirei had bought Vice-President Chiwenga 'a Toyota Lexus under the Command Agriculture programme, to supervise the programme countrywide'. Academic views echo the findings by Kebonang (2005, p. 11), who asserted that patronage and patrimonial contexts are prime in most African states where political power is tailored, and that politics is a form of industry as political positions offer easy access to amassing prospects and state resources. Accordingly, political succession is difficult and complex, because violence, patronage, the rendition of patriotic history, the capture of bureaucracy and social-laxity have been major attributes propelling and sustaining centralism and non-succession. In an interview, a permanent secretary noted that:

Succession politically is complex and difficult. When one is elected into power, the main goal is to maintain and consolidate power, guaranteeing the continuity of the political party and individual position. Administratively, succession is clear because of the system of hierarchy. Once appointed in the ministry, upward mobility is smooth. Permanent secretaries are appointed to a ministry not based on their competences or educational qualification like in South Africa. This enhances transferability not for someone to be a permanent feature of a ministry.

All the respondents concurred with this perception that political succession is difficult due to the disregard of citizens' preferences, political parties' internal democracy, and due process as evidenced in the ascendance to power of both Nelson Chamisa and Emerson Mnangagwa. According to one member of civil society: 
Organised state violence, high-jacking of societal demands, veneration and glorification of political leadership and non-adherence to the precepts of constitutionalism have been the hallmark of Zimbabwean politics.

A major concern is the system of appointing all permanent secretaries that is not based on their technical competences; such an approach breeds a strong patrimonial legacy. The existing appointment process usually results in the retention of the big-man and -woman syndrome consolidating a patronage system, capturing bureaucracy and resulting in a halt to succession and elite circulation. The three permanent secretaries interviewed appeared to believe that in administrative terms, succession is clear and simple. The secretaries argue that upward mobility and administrative progression is constitutionally guaranteed and protected. One permanent secretary interviewed noted that:

The Constitution of Zimbabwe 2013, Section 199-205, guarantees the independence of the civil service in the recruitment of civil servants being the employer. The civil service analyses the integrity of civil servants, guided by the principles of public management, for instance professionalism and meritocracy (section 194-198 of the Constitution of Zimbabwe, 2013). Seniority was or is also considered during promotion and juniors cannot jump frog [sic] seniors basing on competence and should be in accordance with the Constitution and the enabling Act.

(Civil Service Act 2018)

This may be ostensibly true but in reality, political correctness and loyalty to the ruling party are the avenues to any beneficial opportunities, including employment in the public service. Zhou (2013, p. 7) suggests that more often than not the incumbent government has disregarded constitutional provisions in the operationalisation of public management - for instance, the link between public administration and national constitutions; yet government's operations are informed by national constitutions. In addition, constitutions give the critical legal frameworks that manage and legalise the practice of public administration which is practised within the interactive structure of the legislative, judicial and executive arms of government. Through these gate-keeping roles the legislative arm ensures that national administrative structures function within the parameters set by parliament and the constitution (Zhou 2013). The above views by permanent secretaries are contrary to those of representatives of opposition parties, who assert that both the past and present regime in Zimbabwe overlooked and disregarded constitutional guarantees. One member of the opposition commented that: 
Appointment and recruitment of the bureaucracy was or is not based on set constitutional criteria. Senior civil servants were or are recruited based on tribal grounds, perpetuating the patronage system. The civil service commission only rubber stamps appointments done by the party. Public service recruitment disregards competence, capacity and meritocracy which are the defining principles of public administration as outlined in section 194-198 of the Constitution of Zimbabwe, 2013.

Most parastatals and state-owned enterprises are manned by party loyalists who are not necessarily concerned with how the business performs. Instead, they are pre-occupied with what the business can offer the party, for example the appointment of Minister Moyo's wife to head the Ant-corruption Commission, her relative Nyemba to head the National Procurement Board and his friend advocate Martin Dinha to head National Railways of Zimbabwe. The research notes that ethnic divisions in leadership have seen the Zezurisation of the public sector during the Mugabe regime (that is, employment of those Shona from Mugabe's Zezuru ethnic group in Mashonaland and Harare provinces) and the Karangarisation (similarly, the Karanga are Shona predominantly from the two major provinces of Midlands and Masvingo) at the inception of the new dispensation under Mnangagwa. These have supported Zanu-PF in power as most state institutions were manned by Mugabe's friends and relatives from Mberengwa, for instance the appointment of Lawrence Mavima in 2019 as governor of the Midlands province, and retired Brigadier Tapfumaneyi to head the Central Intelligence Organisation. Similarly, Coltart (2008, p. 1) notes that the basis of Zimbabwe's (financial) problems is the wastage resulting from a corrupt political elite which has behaved with absolute latitude for decades. The preceding arguments by members of the opposition differ from members of the Politburo and Central Committee who defended the ruling regime as follows:

When a party is elected into power, it has a manifesto and programs (political, economic and social), that it wants to fulfil. Even in America and Britain as in Zimbabwe, the president appoints like-minded bureaucracy and party members that are compatible politically and ideologically with the party and president's vision. For instance, in America the president can appoint the top four or five in each department or ministry. That is why in Zimbabwe, the president's office will first vet everyone to ascertain their political aptitude, despite the independence and permanency of the Civil Service Commission. Patronage, in the narrow sense, is permissible to achieve the developmental goals of the ruling party and that cannot be eliminated. 
The statements in the preceding excerpts by the members of the Politburo and Central Committee are true even in mature democracies which employ the same strategies, except that they differ on execution, operationalisation and rationale. Mature democracies strive to create strong democratic institutions that respect human rights, the rule of law and constitutionalism, thus promoting seamless power transition and responsive, efficient state administrative structures. The academics argue that the execution, operationalisation and rationale of administrative succession in mature democracies differ considerably from how they are comprehended in Zimbabwe. There patronage acts as a political tool to stifle dissenting voices and capture the bureaucracy, leading to strong personalities and weak state institutions enabling the incumbent government to rule in perpetuity. According to a member of the central committee of the ruling party:

Zanu-PF is a system since the liberation struggle era, and state institution[s] will always be led by leaders who have participated in the liberation struggle [and] who are conversant with the trials and tribulations of the liberation war. The party cannot give political and administration positions to someone who has joined the government for a salary.

Furthermore, political elites sacrifice the country's economic and social welfare for the benefits of their political rule. Diamonds, for instance, are a paramount example of a state resource which is pillaged and plundered through a multifaceted network of army, police, Central Intelligence Organisation (CIO) and senior Zanu-PF officials (Bertelsmann 2016, p. 11).

Engelbert and Dunn (2013, p. 30) disagree with the idea of 'patronage in a constricted logic' by typifying neopatrimonialism as 'a collective of practices and highlights of African political frameworks, defined by private rule, personalisation of legislative issues, the lack of differentiation between public and private realms, institutional weakness, and concurrence of bureaucratic and casual legislative issues and corruption'. They also echo the views of members of academia, observing that 'factionalism is a[n] emblematic feature of neo-patrimonial systems'. Furthermore, they restate the assertion (p. 34) that the struggle for power in Zanu-PF and in Zimbabwean politics in general is mainly about inclusion and marginalisation from the neo-patrimonial supply chain, because:

neopatrimonialism revolves around its polycentric nature, defined by undue number of supporters, such a large number of groups, an excessive number of incessant refashioned and renegotiated proportionate interactions, with the result that economic agents cannot 
factor the expenses or costs of the framework in and remain exposed against its eccentricity.

In an interview, an academic indicated that:

Society has no esteem for collective responsibility. Zimbabweans are concerned with how central and local government levels are supposed to work and deliver, for instance how government is expected to be, and should be responsible, as if members of the executive are the owners of the state. Society does not appreciate ideals of co-ownership, co-developing, co-governing and co-producing.

There is indeed a large element of reciprocity in a patrimonial system, whereby the main patron uses his authority and the legitimacy derived from his dominant family position to appoint others to positions of authority from which they can gather resources for themselves in exchange for their loyalty and for transferring some resources back to him.

The views of respondents as described above were more divided on the implications of succession politics on state administration. The views of academia, think tanks, opposition parties, one permanent secretary and two MPs converged by denouncing political aptitude and party loyalty as the hallmark of sustenance in a patrimonial system and the lengthy survival of Zanu-PF in power. On the other hand, proponents of patronage politics and patrimonial systems defended patronage in the narrow sense in terms of presidential appointments in both the bureaucracy and government. This group included members of the executive, politburo, two MPs and two permanent secretaries. The study established that in Zimbabwe, the government has overlooked constitutional provisions in the operationalisation of public administration and this has compromised the efficacy and responsiveness of state administration. In such a scenario, succession and elite circulation become a challenge, since party gate-keepers and bureaucracy are captured by the incumbent party.

\section{THE LEGACY OF TRADITIONAL SUCCESSION MODELS}

Succession politics has become a topical issue and a perennial challenge in Africa. In this study, respondents had different perspectives on how succession patterns and frameworks prevailing in the continent influence the efficacy of state administration. Members of academia, the executive and bureaucracy concurred that the inheritance of a traditional succession model had a bearing on the succession challenges facing the African continent. According to July Moyo, a 
senior member of Zanu-PF, that party's succession model conforms to the Shona tradition:

In pre-colonial Africa, succession was guaranteed and appointment issues were handled by spirit mediums in line with the different systems pertaining to each culture and tribe during the pre-colonial era like in the American systems, where each battalion has its own chaplain. Africa[n] tradition had two major models of succession, namely the collateral system (which rotates among family in Shona culture) and primogeniture (a chief begets a chief or Induna iyazali Induna in Ndebele culture).

The above views are supported by Chirikure et al. (2016) who posit that rotational political succession (sometimes known as collateral succession) in historical/ archaeological Shona states such as Mutapa and Torwa, followed the system of 'houses', which were essentially ancestries descended from the initiators of explicit political entities. Based on these preceding views, Mutapa kings were selected from the progenies of Nyatsimba Mutota, the founder of the Mutapa state (Mudenge 1988). Nyatsimba Mutota had several sons, each of whom was given a district to rule in the kingdom. The lineages of these sons, over time, became households of power (dzimba dzoushe in Shona) (Chirikure et al. 2016), from which future kings, provincial and district leaders were and still are being drawn. Upon the death of the founder, political succession alternated around these 'houses', beginning with that of the first son to that of the youngest. Furthermore, spirit mediums associated with departed kings or chiefs (mhondoro) played a vital role in royal induction, national prayer, deposing a cruel leader and, among others, communicating with Mwari [God] via ancestors (Lan 1987).

Under this succession system, rotation inferred that when a new leader became the sovereign he did not move into the homestead of his predecessor (Chirikure et al. 2016). Instead, he ruled from his own household which became the new axis of authority, thus reducing succession conflicts since there was no loss of privilege or material substance. In the event of succession, capitals within the state shifted the eminence of entities such as provinces, and districts changed subject to the political configuration of the day (Chirikure et al. 2017).

However, two members of the opposition and two members of think tanks challenged this conception by a member of the executive, arguing instead that despite clear succession patterns in pre-colonial society, there is a tendency by leaders to smuggle traditional succession norms and monarchical tendencies into the modern bureaucratic state so that power is not abandoned or relinquished unless death befalls. One member of the opposition avers that: 
Succession models in modern Africa were cut and pasted from a traditional perspective by politicians to suit their egocentric perceptions. Political leaders in Africa seem to view themselves as the only sacred specie that can rule in perpetuity. The current succession frameworks in Africa are reminiscent of the traditional succession framework.

In the same context, members of the executive, Politburo, Central Committee and academia strongly argued that traditional succession models can be a panacea to African's development and political problems. For them, the models promote continuity and stability in a polity, since authority was recognised as legitimate by virtue of tradition and customs rooted in an ancestral past. A Politburo member argued that:

When modern legal rotational succession models were translated in Africa, the continent struggled to adapt since the models were alien to Africa's political culture. The modern models undermine the revolutionary spirit and Africa's development trajectory, since development dictatorship guarantees continuity and stability.

In analysing the overall responses on the inheritance of traditional succession frameworks, the majority of our informants held the view that succession challenges in Africa are due to the implant of traditional succession models. These informants were mainly the executive members, two Politburo members, two permanent secretaries, one think tank member, two MPs and two members of academia. This category of respondents felt that it was not the length of time someone is in office, but the embedded leadership norms and values exhibited by a leader in fulfilling the aspirations of the people. According to Chirikure (2017), modern succession models involve loss of power and material and influence a situation that exacerbates the succession challenge and non-circulation of elite in Africa.

However, a minority of the respondents differed sharply with the above views, arguing that the current conception and trends of the succession model in modern bureaucratic states now hinge on the similarity of both constitutional and normative values. This category includes members of the opposition, one MP, one think tank member, two members of academia and one permanent secretary. This category of respondents argued that modern states now need to adopt and adapt to the legal rotational succession model. This is supported by Ojo (2012) who alluded to the fact that contemporary governmental and bureaucratic arrangements are the classic procedures of legal rotational authority. Furthermore, for Ojo (2012), the institutions, laws, and legal order are the only source of legitimacy and the law is supreme, not individuals or groups of individuals. 


\section{RELUCTANCE OF AFRICAN LEADERS TO RELINQUISH POWER}

Reluctance to relinquish power influences succession frameworks and the efficacy of state administration in Africa. Respondents argued that politicians in Africa have shown a consistent culture of violating and amending state and party constitutions in order to prolong their stay in power. This has resulted in what Fombad (2008, p.19) refers to as the constitutional coup or a third-term calamity. A member of the legislature argued that:

Succession is difficult in Africa because leaders are not prepared to leave office or do not imagine that any other person can come into office. Normally, African presidents are hesitant to relinquish power. Only in case of health incapacitation and / or when death befalls as in the traditional setup. Mostly, power transitioning periods have resulted in chaos, coups d'état, because of poor succession planning on who takes over next. Also, the truth about African politicians is that they are unprepared to relinquish power.

The above submissions are supported by Igbuzor (2010), who emphasises that human resources and leadership define the accomplishment or failure of organisations and nations, since everything depends on leadership. Igbuzor further suggests that political leadership is imperative for the effective and competent functioning and progress of the state. Therefore, political succession is of intentional significance in the survival and existence of a polity. Political succession therefore pivots on the solidity, survival and improvement of nations; it is thus important to note that in every nation, change is unavoidable. Respondents strongly argued that despite acknowledging the significance of a methodical transfer of power from one person to another by political stakeholders in Africa, the reality in many countries is that they may be ignorant of the rules and procedures of succession. The result is political volatility and legality issues such as the legitimacy crisis in Zimbabwe. The member of the opposition lamented that:

\footnotetext{
Mnangagwa's victory through the Constitutional Court was an affront to democracy and international electoral principles. The courtsmuggled victory was against the interests of Zimbabweans, inducing legitimacy crises by stifling the wishes of the electorates.
}

The respondents' views are buttressed by Jinadu (2008), who claimed that smooth and unified political succession entails observance of rules and regulations. When religiously followed over a long period of time, this observance becomes 
embedded into the political culture of organisations and nations. A good example is the succession process in Rotary clubs where the successor is known over one year in advance. Consequently, in Africa several factors including ideals, political structure, incongruities in the political system, power fights, dictatorial political philosophy and fragile institutions make smooth succession difficult. Zimbabwe is a good example of a country that lacks observance of rules, where there is an immoderate determination to cling to power for life coupled with a frail and compromised opposition, and feeble and ineffectual mass and egalitarian organisations and institutions (civil society) (Jinadu 2008, p. 5).

In this vein, the academics interviewed argued that pre-colonial Africa was defined by an immaculate aesthetic, social harmony and autonomy informed by the philosophy of communalism. Academia blames the attitude and calibre of leaders in Africa, who despite the adoption of a legal rotational succession model still disregard constitutionalism. One academic interviewed acknowledged that:

Discussion around succession was taboo within and outside Zanu-PF and anyone perceived to threaten the late Mugabe's position (even in the Second Republic) was/is labelled the enemy of the state who is against the norms and values of the liberation struggle. The norms and values of succession were or are not institutionalised; leaders and bureaucracy are recycled despite non-performance or lack of competence.

This argument also finds expression in Mpondi (2015), who argues that calls for leadership transformation, progression and power transitioning have divided political parties in Zimbabwe. Purging rebellious voices in Zimbabwe's two main ideological groups and/or political parties resembles a revolution devouring its children, or a hen ingesting its own eggs.

Appetite for absolute power seems to have been inculcated into Zimbabwe's political landscape for a long time without any concomitant guarantee of viable limitations or control of power. Because society created and sustained this culture of centralism and executive dominance, and encouraged a trend of monopolistic power and the abuse of executive authority, ultimately this was responsible for the cult of the 'Big Man', the unchallengeable leader in Zimbabwe.

Mohiddin (2008) concurs with the academics consulted in this research that a major challenge threatening good governance in Africa, with reference to Zimbabwe, is how to compel or limit executive power and balance its discretionary authority while not attenuating its ability to fulfil its legitimate responsibilities or political obligations. Msindo (2016, p. 160) agrees with this sentiment: 
Robert Mugabe did not allow opposition, the late President used more (pliably) brutal tactics, opposing forces were usually struck by a coalition of political and military leaders [who stand] equipped and eager to employ viciousness to effect the treacherous vision of the regime and perpetuate his control of the state.

On the other hand, members of the executive, one MP and members of Zanu-PF's Politburo diverge from the views of most MP's and academia on the reluctance to relinquish power. Their main contention is that during the formative stages of most African states, the incumbent government enjoyed a high degree of goodwill from citizens. Because of the role they played in the liberation struggle they continued enjoying this goodwill from the citizenry because of their incumbent advantage. A member of the executive asserts that:

Most European governance models had no term limits, and this was ingrained in most modern African political systems. When first generation leaders ascended to power, they were very young and managed to attract the goodwill of the masses. Their consistency in winning elections led to the argument that there was no elite circulation or succession.

The paper contends that because they enjoyed incumbent advantage, leaders managed to infiltrate all state institutions. According to one of the academics interviewed in this research:

Society is to blame for creating and sustaining the big man and woman syndrome where leaders were venerated and hero-worshipped, ending up destroying all sectors of the society.

Most of the respondents observed that African leaders disregard and overlook the constitutional clauses which often guarantee two five-year terms for the president. They attacked the democratic centralism and developmental dictatorship which ferment stagnation in succession and abandon the regeneration of governance structures. Major voices in this category were the academics, think tanks, civil society, opposition parties, two MPs and one permanent secretary. Masunungure (2008, p.15) laments the way in which Mugabe overlooked the resolve of the people in the 2008 synchronised elections. The leader's appetite for power led to a vicious government-supported protocol nicknamed CIBD, an acronym for Coercion, Intimidation, Beating, and Displacement, which indulged in the gruesome torture, 
incinerating, kidnapping and killing of citizens. According to these respondents, this culture of violence and dictatorship was used as a trump card to sabotage or postpone leadership renewal and succession.

On the opposite side are the proponents of democratic centralism and developmental dictatorship. They do not subscribe to democratic principles that promote credible, free and fair elections resulting in seamless power transition. Instead, they view governing and ruling as the sole objective of their party and not as a collective procedure. Their scope seems to be constrained because of their role during the decolonisation of Africa, in particular with reference to Zimbabwe. The major advocates in this category were the executive and Politburo members, whose sentiments are captured by Matemadanda, and reported in The Standard newspaper of 15 December 2019 as saying that 'Zanu-PF will rule by hook and crook'. The Secretary of the Commissariat was quoted saying:

This is a revolutionary party that liberated this country, and the only one that can defend the revolution, therefore, we will fight to defend that course by any means necessary. Every election is a process to defend the revolution against Western imperial powers working in cahoots with local puppets. We will use any means necessary to defend the revolution. Elections will not remove Zanu-PF from power. If elections fail, we will use any other means necessary. You are the voice of this country, you are the way of this country, and you are the future of this country. Only Zanu-PF can defend Zimbabwe's integrity and sovereignty.

This perspective aptly captures Mugabe's views after his defeat by Morgan Tsvangirai in the harmonised elections of March 2008:

Zanu-PF struggled for you, for your prerogative, land and a bright future. This legacy ought to not just be outdone by the stroke of a pen at the voting booth because I am not getting critical or elementary goods... Otherwise a candid X would have returned the nation to 1890.

It is the same mentality that is expressed by the proponents of democratic centralism and developmental dictatorship, who strongly believe that the incumbent revolutionary parties have a mandate to administer the country by any means necessary. These views contravene the culture of constitionalism, and result in delayed or postponed succession and/or a chaotic and violent takeover of power. 


\section{CONCLUSION}

The paper has examined the impact of succession politics on state administration, unpacking the relational boundaries and conceptual overlaps of the politicoadministrative interface in Africa. The paper indicates that state formation in Africa has been a victim of colonial legacy, and a traditional succession model whose influence led to modern African administration which is progressively absolutist and autocratic in nature. The adoption of a collusive model anchored in a patrimonial system resulted in a small clique controlling the apparatus and institutions of the state for personal gain. The bureaucracy has been captured and used primarily for rent-seeking purposes. The paper concludes that succession politics and state administration are victims of historical, political, traditional and societal factors that moulded political systems, governance structures and succession patterns in Africa. The paper also asserts that in Zimbabwe the succession dilemma will continue to hound succession trends and responsible administration, unless broad-based reforms are instituted to dismantle the historic legacy imbedded in the political system, and which has emasculated succession procedures.

\section{----- REFERENCES}

Agamben, G 1998, Homo Sacer: Sovereign Power and Bare Life, Stanford University Press, Stanford, Calif.

Berftelsmann Stiftung BTI 2016, Zimbabwe Country Report, http://www.btiproject.org/fileadmin/files/BTI/Downloads/Reports/2016/pdf/BTI_2016_ Zimbabwe.pdf

Bratton, M 2010. "The Meanings of Democracy: Anchoring the "D-Word" in Africa', Journal of Democracy, vol. 21, no. 4, pp. 106-113.

Cedras, J 2013, The interface between Public Administration and Union Politics: The ANC-SACP-COSATU Dialogue in South Africa, University of Pretoria, Pretoria.

Chirikure, SF 2016, 'Decisive evidence for multidirectional evolution of sociopolitical complexity Southern Africa', African Archaeological Review, vol. 33, no. 1, pp. 75-95.

Chirikure, SF 2017, 'No Big Brother Here: Heterarchy, Shona Political Succession and the Relationship between Great Zimbabwe and Khami, Southern Africa', Cambridge Archaeological Journal, vol. 28, no.1, pp. 45-66.

Coltart, D 2008, 'A decade of suffering in Zimbabwe - Economic Collapse and Political Repression under Robert Mugabe', Centre for Global Liberty and Prosperity, pp. 24-35. 
Dashwood, H 2000, Zimbabwe: The Political Economy of Transformation, University of Toronto Press, Toronto.

Devanny, J \& Jowell, M 2018, 'The dictator's dilemma: How to succeed at succession', Mail \& Guardian, 9 April.

Dorman, S 2006, 'Post-liberation politics in Africa: Examining the political legacy of struggle', Third World Quarterly, vol. 27, no. 6, pp. 1085-1101.

Engelbert, P \& Dunn, KC 2013, Inside African politics, Lynne Rienner, Boulder.

Fombad, C 2008, 'Post-1990 Constitutional Reforms in Africa: a Preliminary Assessment of the Prospects for Constitutional Governance and Constitutionalism'. In: A Nhema \& P Zeleza (eds), The Resolution of African conflicts: the management of conflict resolution and post conflict reconstruction, Ohio University Press, Athens, Ohio.

Fombad, C 2008, 'Limits on the power to amend Constitutions: Recent trends in Africa and their potential impact on constitutionalism', Paper presented in Athens, Greece, during the World Congress of Constitutional Law on the theme, Rethinking the Boundaries of Constitutional Law, 11-15 June 2007.

Francisco, A 2010, Neopatrimonialism in Contemporary African Politics, E-International Relations, 1-3.

Govea, RM \& Holm, JD 1998, 'Crisis, violence and political succession in Africa', Third World Quarterly, vol. 19, no. 1, pp. 129-148.

Grindle, M 2012, Jobs for the Boys: Patronage and the State in Comparative Perspective, Harvard University Press, Cambridge, MA.

Habisso, T 2011, 'Politics of succession: coping when leaders die', African Renewal, $1-15$.

Hughes, A \& May, R 1988, 'The politics of succession in Black Africa', Third World Quarterly, vol. 10, no. 1, pp. 1-22.

Igbuzor, O 2010, Electoral violence in Nigeria, Action Aid, Asaba.

Jinadu, L 2008, 'Political succession in Africa', Nigerian Political Science Association ${ }_{\llcorner}$ pp. 1-49.

Lan, D 1987, Guns and Rain: Guerrillas and spirit mediums in in Zimbabwe, James Currey, London.

Kebonang, Z 2005, 'The New Partnership for Africa's Development: Promoting foreign direct investment through moral political leadership', Africa Insight, vol. 35, no. 1, pp. 3-13.

Maphunye, K J 2009, ‘Public Administration for a democratic developmental state in Africa: Prospects and possibilities', Africa Portal.

Masunungure, EV 2008, Defying the Winds of Change: Zimbabwe's 2008 Elections, Weaver Publishers, Harare.

Matunhu, J 2011, 'A critique of modernization and dependency theories in Africa: Critical assessment', African Journal of History and Culture, vol. 3, no. 5, pp. $65-72$. 
Mills, G et al. 2019, Democracy Works: Turning Politics to Africa's Advantage, Hurst \& Company, London.

Mohiddin, A 2008, 'Unchecked Executive Powers: Lessons in Effective Government Design', SAIIA Occasional papers series, pp. 1-8.

Mpondi, D 2015, 'The Institutionalization of One Man Rule and the Politics of Succession and Patronage in Zimbabwe', International Relations and Diplomacy, vol. 3.

Msindo, E 2016,'Factionalism and Robert Mugabe's Leadership in Zimbabwe'. In: E Obadare, \& W Adebanwi, (eds.). Governance and the Crisis of Rule in Contemporary Africa: Leadership in Transformation, SpringerLink, Switzerland. Mudenge, S 1988, A Political History of Munhumutapa, Zimbabwe Publishing House, Harare.

Mwaura, C 1997, Political succession and related conflicts in Kenya, USAID Conference on Conflict Resolution in the Greater Horn of Africa (pp. 1-25), Nairobi, Methodist Guest House.

Nwosu, BU 2012, 'Tracks of the third wave: democracy theory, democratisation and the dilemma of political succession in Africa', Review of African Political Economy, vol. 39, no 131, pp. 11-25.

Ojo, OE 2007, 'Elections: An exploration of theoretical postulations', Journal of African Elections, vol. 6, no. 2, pp. 4-13.

Oyedele, SO 2015, 'The Nigerian public service and service delivery under civil rule', Journal of Public Administration, Finance and Law, vol. 07, pp. 33-43

Zhou, G 2013, 'The challenges of public administration under inclusive models of governments: the case of Zimbabwe', International Journal of Social Science and Humanities, vol. 3, no. 12, pp. 154-164. 